\title{
REGIONAL AND STRUCTURAL DEVELOPMENT OF SPECIALIZED FARMS IN CENTRAL AND EASTERN EUROPEAN COUNTRIES (2005-2016)
}

\author{
Csaba Forgacs ${ }^{1}$, CSC.
}

${ }^{1}$ Corvinus University of Budapest

\begin{abstract}
This paper analyses the structural development of farm specialization in Central and Eastern European countries (CEECS/EU-10²) over the 2005-2016 period with a special focus on regional aspects of such development. We look at the number, land, labour and production of ten specialization types of farming in each of the EU-10 countries using EUROSTAT data, and compare these with the EU-15/27 averages. We conclude that the number of specialized farms in EU-10 declined to a lesser than in the EU-15 but doubled the production against 30 per cent growth in EU-15. The growth of production shows strong regional differences from 50 per cent to 200 in EU-10 and, offering more jobs in three countries in 2016 than in 2005. Cereal farms more than tripled production closing the gap to EU-15 average from two third to 50 per cent. In 2016, already over 75 per cent of the production of specialized farms in CEECs came from TOP 3 specializations (dairy, cereal and pig), well above EU-15 average (55 per cent). From 2005 until 2016 growth of area, labour and total productivity of specialized farms in EU-10 well exceeded that of EU-15. Their levels, however, were still only around 43 per cent, 25 per cent and 20 per cent of that of EU-15 in 2016 . The ratio between the highest and lowest productivity levels within EU-10 is 3.8 with respect to area, 5.2 with respect to labour, and 35.4 with respect to total productivity in 2016 and shows clearly the extent of scattering in the productivity of specialized farms in EU-10 countries.
\end{abstract}

Key words: agriculture, specialization, farm size, productivity, CEECs.

JEL code: Q1

\section{Introduction}

Significant changes in farm structure of the EU-10/15/27 took place between 2005 and 2016. One of the key features of this change is that specialized farms play an increasing role in the production both in the EU-10 and in the EU-15. The higher share in production, land and labour use belongs to different farm types in CEE countries. The aim of the paper is to explore the regional differences in growth of specialized farms by farm types at the EU-10 level and, by farm types in countries and by countries total. Differences between the EU-10 average data and the EU-15 average by specialization types allows one to monitor how effective the catching up in EU-10 agriculture has been by improving specialization. Progress achieved in specialization in EU-10 countries is also compared to the EU-10 and EU-15 average.

\section{Literature review}

Before and after the EU Eastward enlargement small farms have always been an important topic for researchers. In 2005, 53 \% of farms were small (below 5 ha) in the EU-15 and 80 \% in the EU-10 which, in 2016, decreased to $47 \%$ and $76 \%$ respectively, yielding a 63,5\% average for the EU-27. On the one hand, it was underlined that small scale farming gave the only job opportunity for most of the rural population to support family. Therefore, it is a challenge for agricultural policy to pay special attention to this agenda and provide a helping hand to small farms to help them grow and avoid migration from rural to urban areas. Feedback from researches to policy makers emphasized the need for developing policy measures better tailored to this subsector (EP resolution, 2014; Davidova S,-Bailey A, 2014; Davidova S, 2014). Davidova, S. et. al. (2012) pointed out that in five of the EU-10 member states the poorest small farms give the largest cluster and CAP instruments are not efficient to help poor farms. Hornowsky, A. et al. (2020) regarding the Polish case identified three types of small farms as "hobby", "two-occupation" and "professional" farms and confirmed that the development of small farms is particularly influenced by 
external factors (EU funding; national benefits), rather than internal (entrepreneurial) ones. Erjavec, E., et.al. (2014) concluded that most Semi-Subsistence Farms exist to survive rural poverty, and off-farm employment is becoming the predominant strategy. Hubbard, C. et.al. (2014) draw the attention to the fact that small and Semi Subsistence Farms (SSFs) appear to play a wider role in the rural economy, as providers of environmental public goods, supplying speciality foods and ensuring the continuation of local and cultural traditions.

On the other hand, researchers also investigated the possibilities of how small farms themselves could adjust to the changing social and economic environment and be integrated into the fast growing and changing food chains. Research outcomes supported small farms to find the best development path for survival (Csaki C., - Forgacs C., 2008; Gordon M., et al., 2014). Benedek, Z. et. al. (2018) based on a survey identified those factors influencing which phase in marketing channels are more fit to small farms to cooperate. Forgacs (2016) showed that small specialized farms achieved higher growth in total productivity backed by intensive labour use than non-specialized small farms. Large and very large farms in the EU-28 have focused more on taking advantage of specialization by extending their land to more than $90 \%$ of the total utilized agricultural area in 2013 (EUROSTAT 2018, pp. 20). Szabo, L. et.al. (2018) investigated the agricultural performance in Visegrad 4 (V4) countries and confirmed that for a successful catching up V4 countries must invest more in purchasing intensification factors and adjust the structure of assets production specification. Csaki, C., Jambor, A. (2019) analysed the issue of convergence/divergence in Central and Eastern Europe and Commonwealth of Independent States in agricultural productivity and found that CEE and CIS countries have experienced a limited convergence to Western-European standards. Forgacs (2019) concluded that specialized farms in the EU-10 have increased productivity at a higher rate than non-specialized farms. As far as the direction of specialization in CEE countries is concerned, Forgacs (2020) found that in production growth rate, the three leading specialization types of farms were cattle rearing and fattening; cereal, oilseed and protein crops and, fruits and citrus fruits farms.

Research question: Did specialization of agricultural farms help convergence of EU-10 agriculture?

$\mathrm{H} 1$ : Specialization is a development path for EU-10 farms to support convergence.

$\mathrm{H} 2$ : Specialized farms of EU-10 increase their share in land use.

H3: Specialization in CEE countries was a development path to keep more labour in sector.

H4: Dynamics of labour, area and total productivity of specialized farms in EU-10 exceed that of EU-15 resulting in a step ahead in convergence.

H5: Productivity development of specialized farms is a general phenomenon in all EU-10.

\section{Methodology}

The paper gives a comparative analysis of farm size and its dynamics to learn more about farm structure and farm restructuring in EU-10 with a special focus on regional development and specialization. We compiled the basic dataset using 2005-2016 EUROSTAT data on the number, land size (Utilised Agricultural Area, UAA), labour size (Agricultural Working Unit, AWU) and production (Standard Output, SO) of all ten specialized farm types (with UAA only) in all EU-10 member states and the corresponding data for the whole of EU-15 and EU-27. We then computed average farm size by land (UAA/farm) and labour (AWU/farm). In order to analyse the productivity level of CEECs' agriculture we used land (SO/UAA), labour (SO/AWU) and farm productivity (SO/farm) indicators. For a more detailed analysis we calculated ratios for comparison of average figures and distribution of input and output at the country level. To measure the amount of change in inputs, outputs and productivity indicators of all specialized farms of EU-10 we computed a dynamics index for number, land and standard output, and that of -of-productivity indicators 
for land, labour and total farm output. Such an approach makes it possible to gain some insight into the changes of mainstream directions and level of specialization in each 10 CEE countries and to compare them to EU-10/15/27 average.

\section{Research results and discussion}

\section{Radical changes in farm structure in EU-10}

The EU-10 has brought 8.6 million farms and some 100 million new customers to the EU, creating one of the largest single markets with 480 million customers and, increased UAA of the EU by $37.5 \%$. Per capita UAA in the EU-10 was 0.46 ha in 2005, while it was only 0.36 ha in the EU-15. After the eastward expansion, the number of farms in the EU more than doubled, although farm size in the CEECs was predominantly small, with $80 \%$ of the farms having UAA below 5 ha, compared to 53 per cent of farms in the EU-15. It was a challenge to integrate the EU-10 into the EU under the Common Agricultural Policy (CAP) in the phase-in period (2004-2013) with an asymmetric but narrowing gap in subsidies between EU-10 and EU-15 countries. It was also unclear how CEECs would manage the adjustment process under CAP.

In the analysed period, $40 \%$ of the number of non-specialized farms in the EU-10 and $31 \%$ in the EU-15 have disappeared. These figures for specialized farms were more modest, $15.8 \%$ and $18.1 \%$ respectively, providing evidence that specialization in the new member states helped the agriculture sector find a path to growth. Except for small farms, the number of specialized farms in the EU-10 increased in all farm size categories, while in the EU-15 only the number of the largest specialized farms (100 ha and over) increased from 2005 to 2016 . Most farms found cereal production and cattle rearing/fattening best for specialization. In 2016, half or close to half of the farms were already specialized in Czechia, Hungary and Lithuania, the only country where even the number of specialized farms grew compared to 2005.

\section{Fast growth in land use of specialized farms in CEE countries}

In 2005, only $40 \%$ of land (UAA) was used by specialized farms in the EU-10 and $51 \%$ in the old member states that was $54.7 \%$ in EU-10 close to the corresponding measure of $56.3 \%$ in the EU-15 in 2016. In 2005, a third of the cereal farms in the EU-27 were in the EU-10 using $60 \%$ of UAA of the specialized farms, a share that rose to $71.4 \%$ by 2016.12 years after joining the EU, the UAA of specialized farms increased by $40.7 \%$ in the EU-10, and $90 \%$ of the land belonged to cereal and dairy farms. Pig farms have lost more than 600 thousand hectares. The growth in UAA of specialized farms varied by country in the EU-10, ranging from $3.5 \%$ in Slovenia to $77.8 \%$ in Latvia. Baltic countries, Poland and Slovenia more than doubled UAA of cereal farms. Cattle rearing/fattening farms in Bulgaria used 25 times more land in 2016 than in 2005, in Latvia twelve times more, and in Poland 6 times more. In 9 CEECs, pig farms lost land area, while dairy and horticulture indoor farms both lost land area in 7 countries. The Baltic countries have made strong strides in diversification of specialization witnessed by a significant growth of land use in cereal, outdoor horticulture, fruit (except in Latvia), cattle rearing/fattening and poultry production.

\section{Absorbing more labour with regional differences in EU-10}

In 2005, EU-10 countries used $17 \%$ more labour (AWU) in agriculture than the EU-15. Due to technology and farm structure development, by 2016 the EU-10 already offered $5 \%$ fewer agriculture jobs than the EU-15. In 2005, $56.3 \%$ of labour was employed on specialized farms in the EU-15, more than twice of what the EU-10 employed. From 2005 to 2016, labour use (AWU) by specialized farms has declined both in the EU-10 (-5\%) and in the EU-15 (-15\%) but to a lesser extent than the labour use decline across all farms. The labour use of cereal and cattle rearing/fattening farms in the EU-10 helped to slow down the speed of letting people go out from the agriculture sector. 
In 2005, the level of labour use by specialized farms in the EU-10 varied by country with a range of 20 \% in Romania to over 50 \% in Slovenia. Specialized farms already offered some half of the agricultural jobs in the Baltic countries and Slovenia in 2016. Labour was a key factor in extending and deepening the specialization of the EU-10 agriculture and shifting towards a more labour intensive production.

The need for labour on farms depends very much on the type of specialization. In the EU-10, more than a third of the labour on specialized farms had jobs in dairy farms in 2005 showing that replacing labour with capital is very costly. In the Baltic countries, more than $70 \%$ of specialized farm labour was employed on dairy farms in 2005, with an enormous decline to 40-50 \% in 2016. TOP 3 labour intensive specialized farming accounted for $72.5 \%$ of labour use in 2005 which grew to $74.5 \%$ by 2016 .

In 2016, apart from Romania, cereal farms more than doubled labour use in the EU-10 compared to 2005 levels. Cattle rearing/fattening farms offered more jobs in nine countries, while dairy farms offered much fewer jobs in all EU-10 countries. Most of the labour worked on dairy farms in 8 out of EU-10 countries in 2005. In 2016, cereal farms used most labour in 7 out of 10 countries, dairy farms in two countries (Estonia and Latvia) and cattle rearing/fattening in Slovenia. Structural changes in labour use in the EU-10 have been significant over the twelve-year period and look as yet unstable.

\section{High concentration in farm production}

In the EU-10, the production of TOP 3 specialized farms (dairy, cereal and pig farms) amounted to $72,5 \%$ in 2005 and to $77.6 \%$ (dairy, cereals, poultry) in 2016 (Table 1). These figures well exceeded the production of TOP 3 farms in the EU-15 (50-55 \%). In 2005, dairy farms provided the highest production figures in one half of the EU-10, cereal farms in the other half. By 2016, cereal farms led production in already 7 out of 10 countries. Dairy farms were second most productive in six countries. Production in the EU-15 has been more balanced among 7 specialization types, each having over $7 \%$ share in production both in 2005 and 2016. In the EU-10, there were already three countries - Bulgaria and Hungary and Slovenia - where production of TOP 3 specialized farms did not change and ranking was kept from 2005 to 2016. 


\section{Share of production of TOP 3 farm specialization types in EU-10 (2005 and 2016), \%}

\begin{tabular}{|c|c|c|c|c|c|c|c|}
\hline \multirow{3}{*}{$\begin{array}{l}\text { Country } \\
\text { Bulgaria }\end{array}$} & \multicolumn{2}{|l|}{2005} & \multicolumn{2}{|l|}{2016} & \multicolumn{2}{|c|}{$\begin{array}{c}\text { From } 2005 \\
\text { to } 2016\end{array}$} & \multirow[t]{2}{*}{$\begin{array}{c}2016 / \\
2005 \text {, } \\
\%\end{array}$} \\
\hline & TOP 3 & $\%$ & TOP 3 & $\%$ & IN & OUT & \\
\hline & cereal, dairy, poultry & 84.6 & cereal, dairy, poultry & 91.2 & \multicolumn{2}{|c|}{ no change } & 107.8 \\
\hline Czechia & cereal, dairy, pig & 73.5 & cereal, dairy, cat/fat & 79.2 & cat/fat & pig & 107.8 \\
\hline Estonia & dairy, cereal, poultry & 90.9 & dairy, cereal, cat/fat & 97.1 & cat/fat & poultry & 106.8 \\
\hline Latvia & dairy, cereal, poultry & 85.5 & cereal, dairy, pig & 89.4 & rank, pig & poultry & 104.6 \\
\hline Lithuania & dairy, cereal, poultry & 87.2 & cereal, dairy, pig & 93.6 & rank, pig & poultry & 107.3 \\
\hline Hungary & cereal, poultry, dairy & 70.1 & cereal, poultry, dairy & 79.2 & \multicolumn{2}{|c|}{ no change } & 113.0 \\
\hline Poland & dairy, pig, hort. indoor & 70.6 & dairy, cereal, poultry & 71.3 & cereal, poultry & pig, h. indoor & 101.0 \\
\hline Romania & cereal, dairy, poultry & 80.7 & cereal, dairy, pig & 84.5 & pig & poultry & 104.7 \\
\hline Slovenia & dairy, cat/fat, vine & 82.2 & dairy, cat/fat, vine & 75.0 & \multicolumn{2}{|c|}{ no change } & 91.2 \\
\hline Slovakia & cereal, dairy, hort. indoor & 79.0 & cereal, dairy, pig & 83.1 & pig & hort. indoor & 105.2 \\
\hline EU-10 & dairy, cereal, pig & 72.5 & cereal, dairy, poultry & 77.6 & rank, poultry & pig & 107.0 \\
\hline EU-15 & dairy, pig, vine & 51.7 & dairy, cereal, pig & 54.8 & rank, cereal & vine & 106.0 \\
\hline
\end{tabular}

Source: Author's calculation based on EUROSTAT data

The increasing level of concentration of production has been a solid trend in CEE agriculture as part of adjustment to CAP. With the exception of Slovenia, the concertation level of specialized farms' (TOP 3) output increased from 2005 to 2016 in all CEE countries over $90 \%$ in Bulgaria, Estonia and Lithuania.

\section{Changes in farm size and labour use}

The average farm size (UAA/farm) in the EU-10 was about $25-30 \%$ of the average EU-15 farm size between 2005 and 2016. Specialized farms in the EU-10, however, were $37 \%$ and $47.3 \%$ of the size of the average specialized farm size in the EU-15 in those years. Looking at farm size by specialization types we find that cattle rearing/fattening farms were largest followed by cereal farms in 2005 and, along with significance growth in size, also in 2016.

The average farm size of specialized farms shows significant differences among specialization types. The average area of specialized farms grew by $67 \%$ reaching $12 \mathrm{ha}$, well exceeding the average size of all farms ( $8.2 \mathrm{ha}$ ) in the EU-10. The average size of specialized farms by type scattered very much by country. In 2005, small farms were prevalent in Romania, with the average size of cereal farms a mere 7 ha, in sharp contrast to the more than 120 ha in Bulgaria and Czechia. The average dairy farm size was less than 6 ha in Bulgaria and Romania in 2016, while exceeding 300 ha in Czechia and 200 ha in Estonia and Slovakia. In 2016, the land size of poultry farms was exceedingly high in Slovakia (165 ha) and Czechia (140 ha). In 2005, there were only three countries (Bulgaria and Czechia and Estonia) where the average cereal farm size was above 100 ha, and in Estonia pig farms also had more than 100 ha of land on average. In 2016, four specialization types had average farm sizes over 100 ha: cereal and dairy farms in three countries, cattle rearing/fattening and poultry farms in one country each.

Labour use rose significantly in Slovakia (poultry, pig, vine), Czechia (poultry, pig), Poland (poultry, outdoor horticulture, fruits), and Estonia (indoor horticulture). The EU-10 average in per farm labour use increased by $12 \%$ on poultry farms, but this increase was almost ten times higher in Slovakia, more than five times higher in Poland, more than 4 times in Czechia and more than double in Bulgaria. 


\section{Total productivity (SO/farm) of specialized farms}

CEE countries have great potential in land and labour resources but their per farm production was only about 12 \% of the EU-15 average in 2005, with the gap slowly narrowing over 12 years. In catching up cereal and cattle rearing/fattening farms were the leading ones in closing the gap, although in 2016 their per farm output was still only $30 \%$ of the EU-15 average. The largest disparity between EU-10 and EU-15 average productivity is on vine farms where total per farm productivity in EU-10 is just above $5 \%$ of EU-15 average.

Productivity figures (SO/farm) of the EU-10 countries are varied. Farms specialized in cereal production in 5 out of EU-10 already have higher averages than that of the EU-15 demonstrating that the rate at which per farm production catches up to the EU-15 level very much differs by country. Excluding olive farming (it is marginal in EU-10 as it is limited to Slovenia), data on the EU-10 countries in nine specialization types provide 90 observations of specialized farms. Of these in only 11 cases (12\%) do we find that individual EU-10 countries have a higher per farm output than that of the EU-15 average in 2005, with 14 cases in 2016. Not a single EU-10 country's productivity average is over that of the EU-15 in indoor horticulture, vine and cattle rearing/fattening farms. However, outdoor horticulture, dairy and pig farms in the EU-10 strengthened their positions by 2016 when compared to 2005. Figures from 2016 show moderate gains in total productivity of specialized farms in EU-10 over the 2005-2016 period. Czechia is the only country where the national average of per farm output already exceeded that of EU-15 average in 6 out of 7 specialized farm types. In Slovakia, cereal, outdoor horticulture and poultry farms produced a higher per farm national average than that of the EU-15. In Estonia, cereal farms and dairy farms beat the EU-15 average, while Bulgaria and Latvia have better average in cereal production only. In four of the EU-10 countries, there is still no specialization type with per farm production higher than the EU-15 average.

From 2005 to 2016, specialized farms in the EU-10 increased per farm output by 138 \% well above the $58 \%$ EU-15 average. CEE countries show evidence of substantial adjustments in selected specialized farm types leading to the increased average figures. Apart from olive production, growth of per farm output exceeded already EU-15 average in all EU-10 countries. Indices were outstanding in Slovakia (420 \%), Bulgaria (316 \%) and Latvia (>200\%). Growth in per farm output was extremely high in Czechia (pig, $9705 \%$, and poultry,1370 \%). Poland shows high growth in poultry (1800\%), fruits (560 \%), and pig farms (360\%). Slovakia, with larger farms by physical size, increased per farm output in pig, poultry and vine farms by $8000 \%, 4500 \%$ and $2100 \%$ respectively. A high growth of production on dairy farms was a general trend across the EU-10 countries, with outstanding figures in Estonia, Slovakia (590\%), and Czechia (330\%).

\section{Area productivity (SO/UAA) of specialized farms}

The key issue in the catching up of EU-10 agriculture is how fast farms in the EU-10 countries are able to increase competitiveness. This in turn depends substantially on how area productivity can be improved. Growth of per hectare production on EU-10 farms exceeded that of EU-15, but it was still only at a level of $43 \%$ of EU-15 in 2016. Cereal farms in the EU-10 showed the highest growth in productivity reaching $75 \%$ of that of EU-15 average, while cattle rearing/fattening farms reached $60 \%$ of the EU-15 average in 2016. Some specialized farm types in CEE countries achieved growth well above EU-10 average. In 2005, in eight of the ten specialization types the EU-10 country average was above the EU-15 average. Three of these belonged to poultry, two to cattle rearing/fattening and one each to cereal, outdoor horticulture and dairy farms. In four specialization directions (indoor horticulture, vine, fruits and pig production) specialized farms production per ha was below the EU-15 average in all EU-10 countries. From a country point of view, all three Baltic countries had higher productivity in poultry production than the EU-15 average in 2005 . By 
2016, area productivity of selected specialized farms in the EU-10 has reached the EU-15 total average in six countries and in 14 specialized farm types The growth of area productivity of specialized farms in the EU-10 was twice that of the EU-15 $42 \%$ and $20 \%$ respectively. Growth of area productivity of specialized farms were higher in all EU-10 countries than EU-15 average. From 2005 until 2016 specialized farms in Bulgaria, Czechia, Latvia and Slovakia increased area productivity by over 50 \%. Area productivity of cereal farms was more than doubled in 5 out of the EU-10. Specialized farms' area productivity more than doubled on pig farms in 6 countries, on cereal farms in 5 , in outdoor horticulture in 5 , and on dairy and fruit farms in 2 countries each.

\section{Growth of labour productivity (SO/AWU) exceeded area productivity}

EU-10 agriculture has achieved significant growth in labour productivity over the 12 years under consideration. However, the difference between the EU-10 and the EU-15 was still much bigger in labour productivity than in area productivity over 2005-2016 period. There is supporting evidence for this in all specialization types of farming and all EU-10 countries, except for outdoor horticulture in Slovakia.

In 2005, one unit of AWU produced 5.4 times more value in the EU-15 than in the EU-10. This production value figure is almost 25 higher in the case of poultry farms, more than 10 times higher on pig farms and more than 5 times in the other 4 specialized farm categories. Cereal and indoor horticulture farms in the EU-10 fared the best but they still used more than three times more labour than their competitors did in the EU-15. Specialized farms in the EU-10 did their best to reduce their labour use per unit production and, more than doubled their labour productivity on average. Growth was more than three times higher in four countries (Bulgaria, Slovakia, Latvia and Estonia). In 2016, there were four countries in CEE where labour productivity of cereal farms already exceeded $50 \%$ of that of the EU-15. In indoor and outdoor horticulture, as well as in fruit production, three countries each reached the $50 \%$ guideline of the EU-15. Looking at labour productivity by countries, we find that Slovakia had labour productivity that was 4.5 times higher than the EU-15 average on outdoor horticulture farms, with quotients above the guideline in horticulture indoor (81 \%), cereal (76\%), fruit (53\%) and pig farms (51\%). Czechia also neared the EU-15 average in 2016 with quotients of $92 \%$ in cereal, $82 \%$ in fruit, $54 \%$ in horticulture outdoor and $51 \%$ in vine farms. Among the Baltic states, only Estonia has an outstanding labour productivity with $75 \%$ of that of EU-15 on average, and with an $81 \%$ on cereal farms. In Poland, only indoor horticulture farms had high labour productivity with $81 \%$ of that of EU-15 while the ratios of all other specializations are below $33 \%$ of the EU-15 average. Labour productivity of specialized farms in the EU-10 has seen growth from 2005 to 2016, but there is still a wide gap between the EU-10 and EU-15 averages. Although some of CEECs did a good job in few types of specializations, others are still well behind in catching up.

\section{Conclusions}

\section{Justifying hypotheses}

$\mathrm{H} 1$ : Specialization is a development path for EU-10 farms to support convergence: Justified, as share of number of specialized farms in total farms increased from 2005 to 2016 in 9 of EU-10.

$\mathrm{H} 2$ : Specialized farms of EU-10 significantly increase their share in land use: Justified. Specialized farms increased land use in 9 out of EU-10 countries.

H3: Specialization in CEE countries was a development path to keep more labour in sector: Justified. Decline in labour use of specialized farms was moderate compared to that of total farms in EU-10.

H4: Dynamics of labour, area and total productivity of specialized farms of EU-10 exceed EU-15 average. resulting in a step ahead in convergence: Justified. Dynamics of all three productivity indicators of EU-10 were higher than those of EU-15. 
H5: Productivity development of specialized farms is general phenomena in all EU-10: Justified. Productivity development was a general picture in EU-10 and was higher than EU-15 average, however growth of labour productivity of specialized farms was below that of total farms in EU-10.

Growth of production of specialized farms in Central and Eastern European countries was significant between 2005 till 2016 with pronounced regional differences. Further specialization looks the only development path for a successful convergence of EU-10 to EU-15 average. It is supported by the higher growth of inputs, production and productivity indicators of EU-10 compared to EU-15 average narrowing the gap but the latter is still significant.

\section{Bibliography}

1. Benedek, Z., Ferto,I., Molnar, A. (2018). Off to Market: But Which One? Understanding the Participation of Small-scale Farmers in Short Food Supply Chains-a Hungarian Case Study. Agriculture and Human Values. Volume 35, pp 383-39

2. Csaki, C., Forgacs, C. (2008). Smallholders and Changing Markets: Observations on Regional level. Society and Economy. Vol. 30, number 1. June. pp. 5-28.

3. Csaki, C., Jambor, A. (2018). Konvergencia vagy divergencia? Merre tart Kelet-Közép-Európa és a FAK mezőgazdasága? (Convergence or divergence? Where to heading Agriculture of CEECs and CIS?). Budapest. Közgazdasági Szemle. LXV. evf., 2018. October. pp. 1048-1066

4. Davidova, S., Fredriksson, L., Gorton, M., Mishev, P. (2012). Subsistence farming, incomes, and agricultural livelihoods in the new member states of the European Union. Environment and Planning C: Government and Policy. Volume 30.pp. 209-227.

5. Davidova, S. (2014). Small and Semi-Subsistence Farms in the EU: Significance and Development Path. EuroChoices. Vol. 13, number 1. pp. 5-8.

6. Davidova, S., and Bailey, A. (2014). Roles of Small and Semi-subsistence Farms in the EU. EuroChoices. Vol. 13, number 1. pp. 10-13

7. Erjavec, E., Falkowski, J., Juvancic, L. (2014). Structural Change and Agricultural Policy for SSFs: A View from the 2004 NMSs. EuroChoices. Vol. 13, number 1. pp. 41-44.

8. EP Resolution (2014). Motion for A European Parliament Resolution on the future of small agricultural holdings. Retrieved: http://www.europarl.europa.eu/sides/getDoc.do?type=REPORT\&mode=XML\&reference=A7-20140029\&language $=E N \#$ title2. Access: 14.03 .2018 .

9. EUROSTAT (2018). Small and large farms in the EU - statistics from the farm structure survey. pp. 18. Retrieved: https://ec.europa.eu/eurostat/statistics-explained/pdfscache/54736.pdf. Access: 11.03.2020.

10. Forgacs, C. (2016). Is Specialization a Way for small Farms to Adjust in CEE (EU-10). Economic Science for Rural Development 2016. Jelgava. April 21-22. Proceedings. No 42. pp. 221-227.

11. Forgacs, C. (2019). Main drivers of Central and Eastern European Countries' Agriculture in 2005-2013: Specialization and Land Concentration. Proceedings of the 2019 International Conference "Economic Science for Rural development" No 50 Jelgava, LLU ESAF, 9-10 May 2019, pp. 320-327 DOI: 10.22616/ESRD.2019.040

12. Forgacs, C. (2020). In What Direction is Agricultural Specialization Headed in Central and Eastern Europe. Proceedings of the 2020 International Conference "Economic Science for Rural Development" No 53 Jelgava, LLU ESAF, 12-15 May 2020, pp. 48-56

13. Gordon, M., - Salvioni, C., and Hubbard, C. (2014). Semi-subsistence Farms and Alternative Food Supply Chains. EuroChoices. Vol. 13, number 1. pp. 15-18.

14. Hornowski, A., Parzonko, A., Kotyza, P., Kondraszuk, T., Bórawski, P., Smutka, L. (2020). Factors determining the Development of Small Farms in Central and Eastern Poland. Sustainability. Multidisciplinary Digital Publishing Institute (MDPI). ISSN 2071-1050.

15. Hubbard, C., Mishev, P.,Ivonova, N. (2014). Semi-subsistence farms in Romania and Bulgaria: a Survival Strategy? EuroChoices Volume 13. Issue 1. pp. 46-51

16. Szabo, L., Grznar, M., Zelina, M. (2018). Agricultural performance in V4 countries and its position in the European Union. Agri.Econ. - Czech, 64: pp.337-346 